\title{
Design Assessment for Melton Valley Liquid Low-Level Waste Collection and Transfer System Upgrade Project at Oak Ridge National Laboratory, Oak Ridge, Tennessee
}

\author{
DISCLAIMER
}

\begin{abstract}
This report was prepared as an account of work sponsored by an agency of the United States Government. Neither the United States Government nor any agency thereof, nor any of their employees, makes any warranty, express or implied, or assumes any legal liability or responsibility for the accuracy, completeness, or usefulness of any information, apparatus, product, or process disclosed, or represents that its use would not infringe privately owned rights. Reference herein to any specific commercial product, process, or service by trade name, trademark, manufacturer, or otherwise does not necessarily constitute or imply its endorsement, recommendation, or favoring by the United States Government or any agency thereof. The views and opinions of authors expressed herein do not necessarily state or reflect those of the United States Government or any agency thereof.
\end{abstract}

Date Issued-October 1994

Prepared by

Enserch Environmental Corporation

Prepared for

U.S. Department of Energy

Office of Environmental Management

under budget and reporting code EW 20

Environmental Restoration and Waste Management Programs

Oak Ridge National Laboratory

Oak Ridge, Tennessee 37831-6285

managed by

MARTIN MARIETTA ENERGY SYSTEMS, INC.

for the

U.S. DEPARTMENT OF ENERGY

under contract DE-AC05-84OR21400 


\section{DISCLAIMER}

Portions of this document may be illegible in electronic image products. Images are produced from the best available original document. 


\title{
UNITED STATES DEPARTMENT OF ENERGY OAK RIDGE OPERATIONS
}

\author{
PROJECT ORDER NO. 920001.02
}

\section{FFA COMPLIANCE CERTIFICATION}

\author{
FOR \\ THE MELTON VALLEY LLLW \\ COLLECTION AND TRANSFER SYSTEM UPGRADE
}

THIS DOCUMENT IS THE PROPERTY OF THE DEPARTMENT OF ENERGY, PREPARED BY ENSERCH ENVIRONMENTAL CORPORATION UNDER CONTRACT NO. DE-AC05-91OR21928 FOR EXECUTION OR REVIEW OF THE ENGINEERING AND CONSTRUCTION OF THE SUBJECT PROJECT. THE ORIGINAL CERTIFICATIONS AND SUBSEQUENT REVISIONS THEREOF, WITH APPROVAL NAMES, INITIALS, DATES, AND WITH THE P.E. SEAL, ARE MAINTAINED IN THE FILES.

Prepared under the supervision of Thomas W. Sanders Tennessee PE Number 018809

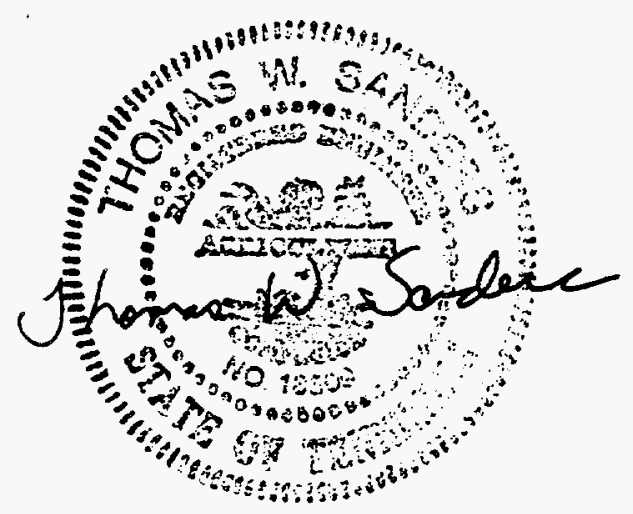

\begin{tabular}{|c|c|c|c|c|c|}
\hline Revision & Prepared by & Reviewed by & Approved by & Date & $\begin{array}{c}\text { Pages Af } \\
\text { fected }\end{array}$ \\
\hline 0 & F. Thomas Waits & John F. Killian & John F. Killian & $2 / 12 / 94$ & All \\
\hline 1 & F. Thomas Waits & John F. Killian & John F. Killian & $4 / 13 / 94$ & All \\
\hline 2 & 7 & $\begin{array}{l}\text { Thomas W. Sanders } \\
\text { J.W. Sa La }\end{array}$ & $\begin{array}{l}\text { Thomas W. Sanders } \\
\text { J.W.S. }\end{array}$ & $10 / 3 / 94$ & All \\
\hline
\end{tabular}




\section{ENSERCH ENVIRONMENTAL CORPORATION}

FEDERAL FACILITY AGREEMENT

APPENDIX F - FY 1992

COMPLIANCE CERTIFICATION - MELTON VALLEY LLLW

CAT SYSTEM UPGRADE PROJECT, ORNL

\section{PROJECT SUMMARY}

This project is designed for collecting Liquid Low Level Waste (LLLW) from generating points inside the Radioisotope Engineering and Development Center (Buildings 7920 and 7930) facility and transferring this waste to the Collection Tank (F-1800) in the new Monitoring and Control Station (MCS) facility. The LLLW is transferred to the MCS in a new, underground, jacketed, stainless steel piping system. The LLLW will then be transferred from Tank F-1800 through a new, underground, jacketed, stainless steel piping system that connects the existing Bethel Valley LLLW Collection System and the Evaporator Facility Service Tanks. The interface for the two systems will be at the existing Interconnecting Pipe Line (ICPL) Valve Box adjacent to the Nonradiological Wastewater Treatment Plant. The project scope consists of the following systems:

(1) Building 7920 LLLW Collection System

(2) Building 7930 LLLW Collection System

(3) LLLW Underground Transfer System to MCS

(4) MCS Building(including all equipment contained therein)

(5) LLLW Under ground Transfer System to ICPL Valve Box

(6) Leak detection system for jacketed piping systems (3) and (5)

\section{B. STANDARDS FOR DESIGN/INSTALLATION OF NEW OR REPLACEMENT TANK SYSTEMS}

\section{REQUIREMENT:}

1(a)

The design/installation assessment for each new or replacement tank system(s) design shall include, at a minimum, the design standards, including available as-built specifications, according to which $\operatorname{tank(s)}$ and/or ancillary equipment are constructed.

\section{ASSESSMENT:}

COMPLIANT - The specifications associated with the equipment(valves, tanks, etc.) and piping furnished with this project have been reviewed and include all of the codes, standards, and design criteria necessary to meet the project requirements. 


\section{ENSERCH ENVIRONMENTAL CORPORATION FEDERAL FACILITY AGREEMENT APPENDIX F - FY 1992 COMPLIANCE CERTIFICATION - MELTON VALLEY LLLW CAT SYSTEM UPGRADE PROJECT, ORNL}

\section{B. STANDARDS FOR DESIGN/INSTALLATION OF NEW OR REPLACEMENT TANK SYSTEMS(cont'd)}

REQUTREMENT:

1(b) The design/installation assessment for each new or replacement tank system(s) design shall include, at a minimum, the hazardous characteristics of the hazardous and/or radioactive substance(s) to be handled (on a tank specific basis).

\section{ASSESSMENT:}

COMPLIANT - The characteristics of the LLLW fluid within the piping and tanks included on this project were assessed. The fluid constituents being handled within the transfer systems and tanks included in this project consist of varying quantities of dilute solutions of $\mathrm{HNO}_{3}, \mathrm{KCl}$, $\mathrm{KClO}_{3}, \mathrm{Na}_{2} \mathrm{CO}_{3}, \mathrm{NaNO}_{3}, \mathrm{KNO}_{3}, \mathrm{NaCl}$ and $\mathrm{NaOH}$ at relatively low temperatures $\left(<120^{\circ} \mathrm{F}\right)$. A listing of some of the fluid properties is included on the project process flow diagrams. In addition to the identification of the constituents, the radionuclides in the fluid being transferred were also identified. Based on this information, the materials of construction of the equipment and piping are acceptable for the application. The vault ceiling and wall concrete thicknesses are provided in accordance with the dictates of Health Physics.

\section{REQUIREMENT:}

1(c)i

The design/installation assessment for each new or replacement tank system(s) design shall include, at a minimum, for new or replacement tank system(s) in which the external shell of a metal tank or any external metal component(s) of the tank system(s) will be in contact with the soil, moisture, or other precipitation a determination by a corrosion expert of the factors affecting the potential for corrosion, including but not limited to: 


\section{ENSERCH ENVIRONMENTAL CORPORATION}

FEDERAL FACILITY AGREEMENT

APPENDIX F - FY 1992

COMPLIANCE CERTIFICATION - MELTON VALLEY LLLW

CAT SYSTEM UPGRADE PROJECT, ORNL

\section{B. STANDARDS FOR DESIGN/INSTALLATION OF NEW OR REPLACEMENT TANK SYSTEMS(cont'd)}

1(c)i (cont'd)
(A) Soil moisture content;
(B) Soil pH;
(C) Soil sulfides:
(D) Soil resistivity;
(E) Structure to soil potential;
(F) Influence of nearby underground metal structures(e.g., piping)
(G) Existence of stray electric currents
(H) Existing corrosion-protection measures (e.g., coating, cathodic protection).

\section{ASSESSMENT:}

COMPLIANT - Cathodic protection has been provided for all of the piping systems that come in contact with the soil. The piping between the ICPL Valve Box and the MCS facility has a galvanic cathodic protection system consisting of sacrificial magnesium anodes connected to the secondary piping with insulated wire. The remainder of the underground piping is provided with an impressed current cathodic protection system using $\mathrm{CuSO}_{4}$ electrodes and magnesium anodes. The systems have been designed by a corrosion expert taking into account, as a minimum, items A thru $\mathrm{H}$ of this section. It is also specified that a corrosion expert will oversee the installation of the cathodic protection system to verify compliance with the design drawings. 


\section{ENSERCH ENVIRONMENTAL CORPORATION \\ FEDERAL FACILITY AGREEMENT \\ APPENDIX F - FY 1992 \\ COMPLIANCE CERTIFICATION - MELTON VALLEY LLLW \\ CAT SYSTEM UPGRADE PROJECT, ORNL}

\section{B. STANDARDS FOR DESIGN/INSTALLATION OF NEW OR REPLACEMENT TANK SYSTEMS(cont'd)}

\section{REQUIREMENT:}

1(c)ii

The design/installation assessment for each new or replacement tank system(s) design shall include, at a minimum, the type and degree of external corrosion protection that are needed to ensure the integrity of the tank system(s) during the use of the system(s), consisting of one or more of the following:

(A) Corrosion-resistant materials of construction such as special alloys, fiberglass reinforced plastic, etc.;

(B) Corrosion-resistant coating (such as epoxy, fiberglass, etc.) with cathodic protection (e.g., impressed current or sacrificial anodes); and

(C) Electrical isolation devices such as insulating joints, flanges, etc.

ASSESSMENT:

COMPLIANT - The pump/valve vault, tank vault and mist eliminator vault are each lined with 11 gauge $304 \mathrm{~L}$ stainless plates on the floor and walls to a level above the capacity of the tank or amount of liquid transferred during one interval. The walls above the stainless steel liner are coated in accordance with the requirements of the vault finish schedules and Division 9, Volume I of the Construction Specification. Each of the pipes in contact with the soil, carrying LLLW that penetrates a structure is provided with an insulating gasket as part of the overall corrosion protection system. Cathodic protection is also provided as described in the assessment for Section B.1(c)i above. 


\section{ENSERCH ENVIRONMENTAL CORPORATION}

FEDERAL FACILITY AGREEMENT

APPENDIX F - FY 1992

COMPLIANCE CERTIFICATION - MELTON VALLEY LLLW

CAT SYSTEM UPGRADE PROJECT, ORNL

\section{B. STANDARDS FOR DESIGN/INSTALLATION OF NEW OR REPLACEMENT TANK SYSTEMS(cont'd)}

\section{REQUIREMENT:}

1(d)

The design/installation assessment for each new or replacement tank system(s) design shall include, at a minimum, for underground tank system components that are likely to be adversely affected by vehicular traffic, a determination of design or operational measures that will protect the tank system against potential damage.

\section{ASSESSMENT:}

COMPLIANT - The underground double-wall piping included in the project will be provided by a Contractor. The Contractor is responsible for the analysis of the piping. The completed analysis will be a deliverable and must be performed and checked in accordance with the site procedures. All of the design criteria necessary for the Contractor to perform the analyses of the various piping systems identified are included in the equipment specification. The design criteria complies with the requirements of this FFA section.

\section{REQUIREMENT:}

1(e)

The design/installation assessment for each new or replacement tank system(s) design shall include, at a minimum, the design considerations to ensure that:

(i) Tank foundations will maintain the load of a full tank;

(ii) Tank systems will be anchored to prevent flotation or dislodgment where the tank system is placed in a saturated zone, or is located within a seismic fault zone which has had displacement during the Holocene period; and

(iii) Tank systems will withstand the effects of frost heave. 


\section{ENSERCH ENVIRONMENTAL CORPORATION \\ FEDERAL FACILITY AGREEMENT \\ APPENDIX F - FY 1992 \\ COMPLIANCE CERTIFICATION - MELTON VALLEY LLLW \\ CAT SYSTEM UPGRADE PROJECT, ORNL}

B. STANDARDS FOR DESIGN/INSTALLATION OF NEW OR REPLACEMENT TANK SYSTEMS(cont'd)

1(e) (cont'd)

ASSESSMENT:

COMPLIANT - Calculations were performed on the tank vault to verify that it is designed to satisfactorily accommodate the loading conditions identified in items (i), (ii) and (iii) above.

REQUIREMENT:

2 The DOE shall ensure that proper handling procedures are adhered to in order to prevent damage to tank system(s) during installation. Prior to covering, enclosing, or placing a new tank system in use, a qualified installation inspector who is trained and experienced in the proper installation of tank systems or components, shall inspect the system for the presence of any of the following items:

(a) Weld breaks;

(b) Punctures;

(c) Scrapes of protective coatings;

(d) Cracks;

(e) Corrosion;

(f) Other structural damage or inadequate construction or installation.

All such discrepancies shall be remedied before the tank system is covered, enclosed, or placed in use. 


\section{ENSERCH ENVIRONMENTAL CORPORATION}

FEDERAL FACILITY AGREEMENT

APPENDIX F - FY 1992

COMPLIANCE CERTIFICATION - MELTON VALLEY LLLW

CAT SYSTEM UPGRADE PROJECT, ORNL

\section{B. STANDARDS FOR DESIGN/INSTALLATION OF NEW OR REPLACEMENT} TANK SYSTEMS(cont'd)

2 (cont'd)

\section{ASSESSMENT:}

DOE OVERSIGHT RESPONSIBILITY. The construction specification imposes inspection requirements on the construction contractor with regard to the items mentioned above.

\section{REQUIREMENT:}

3 The DOE shall obtain and maintain copies of all inspection reports relating to the fabrication, construction, installation, and testing of tank system(s). These reports shall be completed by welding inspectors certified by the American Welding Society.

\section{ASSESSMENT:}

DOE RESPONSIBUITY. Welding inspection certification requirements are included in Division 18, Volume I of the Construction Specification.

\section{REQUIREMENT:}

4 New tank system(s) that are placed underground and that are back filled shall be provided with a backfill material that is a noncorrosive, porous, homogenous substance and that is installed so that the backfill is placed completely around the tank and compacted to ensure that the tank and piping are fully and uniformly supported.

\section{ASSESSMENT:}

COMPLIANT - Excavation, backfilling and compaction for underground piping systems and foundations is adequately covered in Division 2, Volume I, Sections 02223, 02225 and 02230 of the Construction Specification. 


\section{ENSERCH ENVIRONMENTAL CORPORATION}

FEDERAL FACILITY AGREEMENT

APPENDIX F - FY 1992

COMPLIANCE CERTIFICATION - MELTON VALLEY LLLW

CAT SYSTEM UPGRADE PROJECT, ORNL

\section{B. STANDARDS FOR DESIGN/INSTALLATION OF NEW OR REPLACEMENT TANK SYSTEMS(cont'd)}

\section{REQUIREMENT:}

5 All new tanks and ancillary equipment shall be tested for tightness prior to being covered, enclosed, or placed in use. If a tank system is found not to be tight, all repairs necessary to remedy the leak(s) in the system shall be performed prior to the tank system being covered, enclosed, or placed into use.

\section{ASSESSMENT:}

COMPLIANT - The construction specification requires that all of the equipment and piping installed will be tested for tightness upon completion of fabrication and/or installation and prior to start-up by the Contractor.

\section{REQUIREMENT:}

6 Ancillary equipment shall be supported and protected against physical damage and excessive stress due to settlement, vibration, expansion,or contraction.

\section{ASSESSMENT:}

COMPLIANT - The tanks and piping associated with this project are supported in accordance with the established design criteria to protect against damage due to thermal, deadweight and seismic loading.

\section{REQUIREMENT:}

7 The DOE shall provide the type and degree of corrosion protection recommended by a qualified corrosion expert, based on the information provided under Subsection 1(c), above, or other corrosion protection if the EPA/TDHE determines other corrosion protection is necessary to ensure the integrity of the tank system during use of the tank system. The installation of a corrosion protection system that is field fabricated shall be inspected by 


\section{ENSERCH ENVIRONMENTAL CORPORATION}

FEDERAL FACILITY AGREEMENT

APPENDIX F - FY 1992

COMPLIANCE CERTIFICATION - MELTON VALLEY LLLW

CAT SYSTEM UPGRADE PROJECT, ORNL

B. STANDARDS FOR DESIGN/INSTALLATION OF NEW OR REPLACEMENT TANK SYSTEMS(cont'd)

7 (cont'd)

a qualified DOE (or DOE-contractor) corrosion expert to ensure proper installation.

\section{ASSESSMENT:}

COMPLIANT - A corrosion expert designed the cathodic protection system. In addition, the construction specification identifies that a corrosion expert will overview the installation of the cathodic protection system to ensure that it is installed and tested correctly.

\section{REQUIREMENT:}

8 The DOE shall ensure that a qualified corrosion expert has provided design guidance during the design of the tank system(s). A qualified corrosion expert shall verify the use of this guidance before construction of the tank system(s) and prior to start-up of the tank system(s).

ASSESSMENT:

COMPLIANT - Refer to the assessment in Section B.7 above.

\section{REQUIREMENT:}

9 The DOE shall maintain at its facility the information or written statements by those persons required to certify the design of the tank system(s) and review the installation of the tank system(s) in accordance with the requirements of B.1 through B.9 of this Subsection, that shows that the tank system(s) was properly designed and installed and that repairs, pursuant to B.2 and B.5 of this Subsection, were performed. 


\section{ENSERCH ENVIRONMENTAL CORPORATION}

FEDERAL FACILITY AGREEMENT

APPENDIX F - FY 1992

COMPLIANCE CERTIFICATION - MELTON VALLEY LLLW

CAT SYSTEM UPGRADE PROJECT, ORNL

\section{B. STANDARDS FOR DESIGN/INSTALLATION OF NEW OR REPLACEMENT TANK SYSTEMS(cont'd)}

9 (cont'd)

\section{ASSESSMENT:}

DOE REQUIREMENT - This document fulfills the project design certification requirements of this subsection.

\section{STANDARDS FOR CONTAINMENT/RELEASE DETECTION}

\section{REQUIREMENT:}

1(a) At a minimum, secondary containment system(s) shall be constructed of or lined with materials that are compatible with the waste(s) or substance(s) to be placed in the tank system and shall have sufficient strength and thickness to prevent failure owing to pressure gradients (including static head and external hydrological forces), physical contact with the waste(s) or substance to which it is exposed, climatic conditions and the stress of daily operation (including stresses from nearby vehicular traffic).

\section{ASSESSMENT:}

COMPLIANT - The tank and equipment vaults designed for the MCS Building have been designed to withstand the static, hydrological and seismic external forces(including vehicular traffic). Compliance of the external, underground piping with the appropriate design criteria(e.g., static, vehicular, hydrological and seismic loading) is the responsibility of the Piping Contractor. The Double-wall Piping Specification provides adequate guidance for the Contractor in this regard. The design criteria included within the Double-wall Piping Specification complies with the requirements of this FFA section. 


\section{ENSERCH ENVIRONMENTAL CORPORATION}

FEDERAL FACILITY AGREEMENT

APPENDIX F - FY 1992

COMPLIANCE CERTIFICATION - MELTON VALLEY LLLW

CAT SYSTEM UPGRADE PROJECT, ORNL

\section{STANDARDS FOR CONTAINMENT/RELEASE DETECTION(cont'd)}

\section{REQUIREMENT:}

1(b) At a minimum, secondary containment system(s) shall be placed on a foundation or base capable of providing support to the secondary containment system, resistance to pressure gradients above and below the system, and capable of preventing failure due to settlement, compression, or uplift.

\section{ASSESSMENT:}

COMPLIANT - The equipment vaults in the MCS Building were designed in accordance with foundation loading calculations that were performed. The criteria used for the calculations is sufficiently conservative. Divisions 2 and 3 , Volume I of the Construction Specification provide satisfactory guidance for the preparation of the sub-foundation and the installation/erection of the foundation(s).

\section{REQUIREMENT:}

1(c) At a minimum, secondary containment system(s) shall be provided with a leak-detection system that is designed and operated so that it shall detect the failure of either the primary or secondary containment structure or the presence of any measurable release of hazardous or radioactive constituents, hazardous substances, or accumulated liquid in the secondary containment system within 24 hours, or at the earliest practical time if the DOE can demonstrate that existing detection technologies or site conditions will not allow detection of a release within 24 hours. 


\section{ENSERCH ENVIRONMENTAL CORPORATION FEDERAL FACILITY AGREEMENT \\ APPENDIX F - FY 1992 \\ COMPLIANCE CERTIFICATION - MELTON VALLEY LLLW \\ CAT SYSTEM UPGRADE PROJECT, ORNL}

\section{STANDARDS FOR CONTAINMENT/RELEASE DETECTION(cont'd)}

1(c) (cont'd)

\section{ASSESSMENT:}

COMPLIANT - The piping and MCS equipment vaults are each provided with an adequate leak detection system that meets the requirements of this section. The double-walled LLLW transfer line from the MCS to the ICPL Valve Box has its annulus continuously pressurized with nitrogen gas at approximately 50 psi above its operating pressure $(\approx 300 \mathrm{psig})$. The double-walled transfer piping from the REDC buildings to the MCS will have the piping annulus pressurized at approximately $125 \mathrm{psig}$. The annulus of all double-walled piping on this project are provided with instrumentation that will annunciate in the MCS control room when the annulus pressure decays. The LLLW Collection Tank(F-1800) vault has a sump that is also provided with instrumentation which annunciates in the MCS Control Room if a leak is indicated.

\section{REQUIREMENT:}

1(d) At a minimum, secondary containment system(s) shall be sloped or otherwise designed or operated to drain and remove liquids resulting from leaks, spill, or precipitation. Liquids may be allowed to accumulate in a secondary containment system sump for up to one week. Spilled or leaked substances and accumulated precipitation that exceed the capacity of the secondary containment system sump shall be removed from the secondary containment system within 24 hours, or in as timely a manner as is possible to prevent harm to human health and the environment, if the DOE can demonstrate that removal of the released substances or accumulated precipitation cannot be accomplished within 24 hours. 
ENSERCH ENVIRONMENTAL CORPORATION

FEDERAL FACILITY AGREEMENT

APPENDIX F - FY 1992

COMPLIANCE CERTIFICATION - MELTON VALLEY LLLW

CAT SYSTEM UPGRADE PROJECT, ORNL

\section{STANDARDS FOR CONTAINMENT/RELEASE DETECTION(cont'd)}

1(d) (cont'd)

\section{ASSESSMENT:}

COMPLIANT - The piping within the scope of the project is sloped at a minimum of $1 / 8$ " per foot to either a source or receiver tank. Leak detection is provided for all jacketed piping such that a loss of annulus pressure, indicating a leak in either the core or jacket piping, would be annunciated in the MCS control room. The MCS Collection Tank vault is provided with a sump and the floors of the cells within the vault, e.g., transfer pumps, transfer valves and mist eliminator) are sloped to drain to this sump. Level instrumentation is provided in the sump to annunciate in the MCS control room upon indication of liquid accumulation in the sump.

Any indication of leakage in the underground piping would result in immediate shutdown of the line with the leak, pending repair of the leaking section of pipe. Since an indication of leakage in the tank vault does not create an immediate health hazard to personnel. The only immediate action necessary is to isolate flows in the vault pending location and repair of the leak.

\section{REQUIREMENT:}

1(e) At a minimum, secondary containment system(s) shall include one or more of the following devices:

(i) A liner (external to the tank);

(ii) A vault;

(iii) A double-walled tank;

(iv) An equivalent device approved by EPA. 


\section{ENSERCH ENVIRONMENTAL CORPORATION FEDERAL FACILITY AGREEMENT \\ APPENDIX F - FY 1992 \\ COMPLIANCE CERTIFICATION - MELTON VALLEY LLLW \\ CAT SYSTEM UPGRADE PROJECT, ORNL}

C. STANDARDS FOR CONTAINMENT/RELEASE DETECTION(cont'd)

1(e) (cont'd)

ASSESSMENT:

COMPLIANT - The vault for the equipment and tanks in the MCS Building are each provided with an 11 gauge stainless steel liner which covers the floor and walls of each vault cell to a elevation which permits containment of volume of liquid in excess of either the tank volume or the volume of liquid transferred at one time. The vault containing these equipment and tanks is designed to withstand static, hydrological and seismic loads. In addition, the tank vault cell is provided with a sump that is continuously monitored for level indication. The underground, piping systems which transfer LLLW are jacketed with stainless steel piping to provide secondary containment. The annulus between the core and jacket piping are provided with leak detection systems consisting of pressurized nitrogen gas. Each piping system that is longer than 500 feet is provided with a segmented annulus to facilitate leak location. The annulus pressure is continuously monitored in the MCS control room.

\section{REQUIREMENT:}

1(f)(i)(A) The external liner shall also be designed or operated shall contain 100 percent of the capacity of the largest tank within its boundary.

\section{ASSESSMENT:}

COMPLIANT - The liner surrounding the Collection Tank(F-1800) is capable of containing a volume of liquid greater than the capacity of the Collection $\operatorname{Tank}(10,000$ gallons) which is the largest tank within the boundary. 


\section{ENSERCH ENVIRONMENTAL CORPORATION}

FEDERAL FACILITY AGREEMENT

APPENDIX F - FY 1992

COMPLIANCE CERTIFICATION - MELTON VALLEY LLLW

CAT SYSTEM UPGRADE PROJECT, ORNL

C. STANDARDS FOR CONTAINMENT/RELEASE DETECTION(cont'd)

\section{REQUIREMENT:}

1(f)(i)(B) The external liner shall also be designed or operated to prevent run-on or infiltration of precipitation into the secondary containment system unless the collection system has sufficient excess capacity to contain run-on or infiltration. Such additional capacity shall be sufficient to contain precipitation from a 25-year, 24-hour rainfall event.

ASSESSMENT:

COMPLIANT - The below grade piping penetrations through building foundations and/or equipment vaults are designed to eliminate infiltration of precipitation. The design of these penetrations is consistent with existing below grade foundation penetrations.

REQUIREMENT:

1(f)(i)(C) The external liner shall also be free of cracks or gaps.

ASSESSMENT:

COMPLIANT - Inspection requirements for vault liners provided in the Construction Specification require that the liners be free of cracks or gaps.

\section{REQUIREMENT:}

1(f)(i)(D) The external liner shall also be designed and installed to surround the tank completely and to cover all surrounding earth likely to come into contact with the substances if the substances are released from the tank(s) (i.e., capable of preventing lateral as well as vertical migration of the substance(s). 


\section{ENSERCH ENVIRONMENTAL CORPORATION}

FEDERAL FACILITY AGREEMENT

APPENDIX F - FY 1992

COMPLIANCE CERTIFICATION - MELTON VALLEY LLLW

CAT SYSTEM UPGRADE PROJECT, ORNL

C. STANDARDS FOR CONTAINMENT/RELEASE DETECTION(cont'd)

1(f)(i)(D)(cont'd)

ASSESSMENT:

COMPLIANT - Tank F-1800 is located in a stainless steel lined concrete vault. The function of the liner is to provide adequate secondary containment for the liquid in the tank or being transferred to the tank and not to necessarily prevent migration to the tank from the surrounding earth. The vault does extend above grade level and does protect against vertical and horizontal migration from the surrounding earth to the tank.

REQUIREMENT:

1(f)(ii)(A) The vault system shall be designed or operated to contain 100 percent of the capacity of the largest tank within its boundary.

ASSESSMENT:

COMPLIANT - The vault containing the F-1800 Collection Tank is lined with an 11 gauge stainless steel liner that extends up the walls of the vault far enough to accommodate either the 10,000 gallon tank capacity or the capacity of a single transfer of LLLW to the tank.

\section{REQUIREMENT:}

1(f)(ii)(B)1 The vault systems shall also be designed or operated to prevent run-on or infiltration of precipitation into the secondary containment system unless the collection system has sufficient excess capacity to contain run-on or infiltration. Such additional capacity shall be sufficient to contain precipitation from a 25-year, 24-hour rainfall event and be constructed with chemical-resistant water stops in place at all joints (if any). 
ENSERCH ENVIRONMENTAL CORPORATION

FEDERAL FACILITY AGREEMENT

APPENDIX F - FY 1992

COMPLIANCE CERTIFICATION - MELTON VALLEY LLLW

CAT SYSTEM UPGRADE PROJECT, ORNL

C. STANDARDS FOR CONTAINMENT/RELEASE DETECTION(cont'd)

1(f)(ii)(B)1

ASSESSMENT:

COMPLIANT - The tanks associated with this project are enclosed in covered vaults. The subsurface penetrations into these vaults, including the ICPL Valve Box, are provided with chemical-resistant water stops designed to prevent precipitation in-leakage, consistent with existing penetration designs.

\section{REQUIREMENT:}

1(f)(ii)(B)2 The vault shall be provided with an impermeable interior coating or lining that is compatible with the stored waste and that will prevent migration of waste into the concrete.

ASSESSMENT:

COMPLIANT - The vault structure housing the equipment and tanks that contain or transfer LLLW is provided with an 11 gauge stainless steel liner that extends, in each cell, above the top the equipment or tank located in that cell. The vault walls above the liners are coated with an impermeable coating consisting of an epoxy primer and top coat which are suitable for the LLLW contained or transferred in the vault cells.

\section{REQUIREMENT:}

1(f)(ii)(C)1

The vault system shall be provided with a means to protect against the formation of and ignition of vapors with in the vault, if the substances being stored or treated meet the definition of ignitable waste under 40 CFR \$262.21. 


\title{
ENSERCH ENVIRONMENTAL CORPORATION FEDERAL FACILITY AGREEMENT APPENDIX F - FY 1992 COMPLIANCE CERTIFICATION - MELTON VALLEY LLLW CAT SYSTEM UPGRADE PROJECT, ORNL
}

\author{
C. STANDARDS FOR CONTAINMENT/RELEASE DETECTION(cont'd) \\ 1(f)(ii)(C)1 (cont'd)
}

ASSESSMENT:

COMPLIANT - Tank F-1800 is provided with a ventilation system that moves air through the tank at a rate of $100 \mathrm{ft}^{3} / \mathrm{min}$. This is adequate to remove any accumulation of ignitabie that might develop from the substances contained in the tank. In addition, the temperature maintained inside the tank is less than the lowest flash point of any substance in the tank. A detonation involving the vapors from the combustible liquids in Tank F-1800 resulting from either direct initiation or a transition from a deflagration to detonation is not considered credible.

REQUIREMENT:

1(f)(ii)(C)2

The vault system shall be provided with a means to protect against the formation of and ignition of vapors with in the vault, if the substances being stored or treated meet the definition of reactive waste under 40 CFR \$262.21, and may form an ignitable or explosive vapor.

ASSESSMENT:

COMPLIANT - The ventilation system for Tank F-1800 provides sufficient circulation through the tank to preclude the possibility of detonation of any explosive vapors such as hydrogen developed from radiolysis within the LLLW in the tank. Even with the ventilation system shutdown and sealed for approximately one month, the hydrogen concentration would only build to the lower 


\section{ENSERCH ENVIRONMENTAL CORPORATION}

FEDERAL FACILITY AGREEMENT

APPENDIX F - FY 1992

COMPLIANCE CERTIFICATION - MELTON VALLEY LLLW

CAT SYSTEM UPGRADE PROJECT, ORNL

C. STANDARDS FOR CONTAINMENT/RELEASE DETECTION(cont'd)

1(f)(ii)(C)2 (cont'd)

flammability limit. Therefore, a detonation involving combustible vapors resulting from radiolysis in Tank F-1800 is not considered credible.

REQUIREMENT:

1(f)(ii)(D)

The vault system shall be provided with an exterior moisture barrier or be otherwise designed or operated to prevent migration of moisture into the vault if the vault is subject to hydraulic pressure.

ASSESSMENT:

COMPLIANT - The vault system included within this project is provided with an external moisture barrier in accordance with the requirements of Division 7, Volume I of the Construction Specification. The membrane waterproofing system is consistent with good industry practice.

\section{REQUIREMENT:}

1(f)(iii)(A) Double-walled tanks requirements.

ASSESSMENT:

Not applicable to this project.

REQUIREMENT:

1(f)(iv)

Ancillary equipment shall be provided with secondary containment (e.g., trench, jacketing, double-walled piping) that meet the requirements of this agreement. 
ENSERCH ENVIRONMENTAL CORPORATION

FEDERAL FACILITY AGREEMENT

APPENDIX F - FY 1992

COMPLIANCE CERTIFICATION - MELTON VALLEY LLLW

CAT SYSTEM UPGRADE PROJECT, ORNL

C. STANDARDS FOR CONTAINMENT/RELEASE DETECTION(cont'd)

1(f)(iv)(cont'd)

ASSESSMENT:

COMPLIANT - The outside, underground piping systems included in the scope of this project are each provided with piping jackets for secondary containment. The annulus of each system is continuously pressurized with nitrogen gas at a pressure higher than the operating pressure in that system. In addition, the piping annulus in each of these systems are continuously monitored in the MCS control room for any pressure decay, indicating a leak in either the core or jacket piping. 
DOE/OR/01-1258\&D2

\section{DISTRIBUTION}

1. A. D. Clay

2. J. T. Etheridge

3. J. R. Macon

4-5. T. H. Monk

6. E. C. Phillips

7. J. L Stellern

8. R. C. Stewart

9. P. S. Wood

10. ORNL ER Document Management Center

11. Central ER Document Management Center

12. Laboratory Records Department

13. ORNL Patent Section

14. Central Research Library

15. Office of Assistant Manager for Energy Research and Development, DOE Oak Ridge Operations Office, P.O. Box 2001, Oak Ridge, TN 37831-8600

16-17. Office of Scientific and Technical Information, P.O. Box 62, Oak Ridge, TN 37831

18. R. O. Hultgren, DOE Oak Ridge Operations Office, P.O. Box 2001, Oak Ridge,TN 37831-8541

19. C. S. Mims, DOE Oak Ridge Operations Office, P.O. Box 2001, Oak Ridge, TN 37831-8541

20. L. L. Radcliffe, DOE Oak Ridge Operations Office, P.O. Box 2001, Oak Ridge, TN 37831-8541

21. L. C. M. Roddye, DOE Oak Ridge Operations Office, P.O. Box 2001, Oak Ridge, TN 37831-8541 